\title{
Collaboration Between Staff and Students in the Scholarship of Teaching and Learning: The Potential and the Problems
}

\section{ABSTRACT}

Collaboration is identified as a key feature of pedagogic action research (see Norton, 2009), which is often a core part of Scholarship of Teaching and Learning (SoTL) methodology. Despite this, there appear to be few articles which explore experiences of collaborative partnerships within SoTL. This paper is a personal reflective essay which critically examines the extent to which 'collaboration' occurred in a SoTL project designed to explore staff and student use of technology (Allin, Turnock and Thompson, 2011). I critically reflect on the nature of student involvement throughout the project and question whether true collaboration between staff and students can ever be achieved due to the power relations that exist within the current higher education system (Mann, 2001). Developing effective collaborations between students and lecturers matters for SoTL practice, as such collaborations have the potential to transform teaching and learning in Higher Education, and develop further our understanding of learning (Werder and Otis, 2009).

\section{KEYWORDS}

collaboration, Scholarship of Teaching and Learning (SoTL), students as researchers, power relations

\section{INTRODUCTION}

Boyer (1990) identifies the scholarship of teaching as the practice "which both educates and entices future scholars" (p.23). In this, Boyer clearly identifies key elements in his view of the scholarship of teaching worthy of further thought. That is, the scholarship of teaching requires intellectual commitment; it concerns the purposes of education and motivation and teachers as learners; it involves communication; and it also involves enlightenment (of students) as to what is important knowledge. The elements of communication and building relations with students - to enable them to see why what they are learning "matters" (Kreber, 2007, p.2. their italics)—is also highlighted in more recent conceptualisations of the Scholarship of Teaching and Learning (SoTL) as "authentic practice" (p.1). As such, collaboration with students is a goal for SOTL, which is identified as significant by several authors (Felton, 2013; Werder \& Otis, 2009). These authors 
further indicate that effective collaboration between lecturers and students is vital, because it has the potential to transform teaching and learning in higher education. However, true collaboration with students is not easy to achieve in higher education, due to the power relations that exist between lecturers and students (Mann, 2001). Moreover, there seem to be few articles that reflect critically on the extent to which collaborative relations with students are achieved in practice. In this paper, I critically reflect on a SoTL research project that I pre-reflexively proposed as collaborative in nature, and uncover the subtle and unconscious ways in which traditional knowledge structures were at times perhaps more reinforced than transformed.

\section{THE SOTL PROJECT}

The SoTL project was designed to enhance student e-learning, based on knowledge generated from staff and students. The project was initially conceptualised to solve a problem of a lack of engagement by students in current e-learning practices in the department, and also, involved working with a colleague in the university learning and teaching academy who was head of e-learning. My involvement of students at the time was based on my constructivist philosophy, emphasising the view that learning occurs through interactions with others (Palincsar, 1998) and my belief that it was important for students and staff to come to a shared understanding of the use of technology in learning, in order to underpin enhancements. It was also based on my learning from a previous module on research-informed teaching I had undertaken as part of my continuous professional development, whereby the benefits for students in engaging in research were identified (see, for example, Brew, 2003; Healey, 2005). As well as in SoTL literature, a constructivist underpinning and the value of collaboration is also reflected in e-learning literature, where scholars (e.g., Salmon 2007) have built models of e-learning showing how e-activities, including discussion boards and use of chat rooms, can be designed to engage students in meaning making through collaborative learning with other students. At the same time, e-learning literature also identifies a lack of understanding of how students engage with new technologies (Sharpe et al., 2005) and the historical development and use of sites such as Blackboard for transmission of information rather than as vehicles for learning.

The initial research questions being examined were: (1) How do staff and students perceive and use technology in their teaching/learning? and (2) What enhancements would each like to see? The study gained clearance from the University School of Life Sciences ethical committee and took place through the academic year 2009. Initially, all undergraduate and postgraduate students on sport courses were emailed with an information sheet and consent form, inviting them to attend focus groups to gauge their current familiarity with emerging technologies, their current experiences, and their views on potential e-learning enhancements. Eleven undergraduate students and ten postgraduate students returned consent forms and took part at this stage. These students were then invited to consent to a further meeting to discuss with me the themes and ideas that emerged from the focus groups and to identify potential enhancement ideas to be used to form the basis of a survey to both staff and students. Once the questionnaire was designed, the students were emailed again to give their comments and invited to help with the survey data collection.

Three undergraduate students responded with comments and interest, and two ultimately worked together to collect the student data. They did this at the end of identified 
lecture sessions, providing an explanation of the project and its intentions to their fellow students before distributing questionnaires and consent forms. I then distributed the staff questionnaire through hard copies in staff mailboxes, having explained the project in an email and in a staff meeting. All questionnaires remained anonymous, with 344 student questionnaires and 30 staff questionnaires returned. The two students who helped with data collection were subsequently invited to discuss and give feedback on the results, and to aid in dissemination events. One of these students helped with an in-house dissemination across the university and an external conference presentation. Full details of the project findings are available in the conference proceedings (Allin, Turnock, \& Thompson, 2011). This reflective paper focuses on the project process and in particular, the issue of collaboration.

\section{ISSUES IN COLLABORATIVE PROJECTS WITH STUDENTS IN HIGHER EDUCATION}

According to Dillenbourg (1999), "collaborative learning" involves "a situation in which two or more people learn or attempt to learn something together" (p. 1). Some authors make a distinction between the terms "co-operation" and "collaboration," whereby collaboration implies greater sharing and equality of partnerships. However, both involve working together with other people, with a shared understanding and working towards shared goals. Solomon, Boud, Leontios, and Staron (2001), further note that collaboration is not static; rather, it is, "a dynamic process that has to be reinvented at each stage of development. It involves attending to personal relationships, the dynamics of working groups and the stakes of the various partners" (p.141).

To understand some of the issues associated with collaborative projects with students in higher education, I referred to the writings by Mann (2001) who, in turn, draws on the work of Foucault to explore the power/knowledge nexus within universities, noting that within this context, social relations are "hierarchically organised according to presumed levels of expertise" (p. 130), and that power operates in both direct and indirect ways, through accepted discourses and practices. Although she recognises that students also have power and that power relations can change, Mann is keen to point out that power is always present, and whether consciously or unconsciously, "operates to enable or limit the individual student" (p.67). For the most part in terms of learning and our relations with students, therefore, the power resides with the authority of the lecturer and is often reinforced through our social practices of teaching and our interactions. The reality of greater knowledge and expertise of lecturers in many areas of learning needs to be recognised. However, it is important not to make assumptions and to take time to understand and listen to the student voice. Fielding (2001) also supports this view, suggesting that, whilst as teachers we may have laudable intentions, we have a tendency to be "unwittingly manipulative" (p. 123) in our dealings with students, often speaking for students and misunderstanding or interpreting their viewpoints, rather than allowing them to truly speak for themselves:

On the one hand, teachers, researchers, parents and adults in general speak too readily and too presumptuously on behalf of young people whose perspective they often misunderstand and, in many contexts, frequently disregard (Fielding, 2001, p.123). 
Recognising a tendency to view professional researchers (academics) as more capable than students in defining problems and undertaking the research process is also evident within the research informed teaching literature. Even with a more inclusive view of scholarship as involving both teaching and research, students tend to be viewed as beginning researchers, learning to become members of a research community (Brew, 2003) requiring facilitation by lecturers to develop along a continuum of research skill development (Willison \& O’Regan, 2007). Hence traditional power boundaries between lecturer and student remain. Moreover, the extent of student involvement in research with lecturers and their perceptions of who does research varies by discipline: for example, in a study by Robertson and Blackler (2006), students of English viewed themselves more as collaborators in research with lecturers than students in subjects such as physics who saw research as being done by lecturers alone. In most contexts, students are usually seen as apprentices in research, under the supervision of academics, rather than as equal collaborators or partners. Indeed, this is supported by Brew (2006), who further suggests that even questioning students on their views of research is laden with power relations as such questions "are asked in the context of hierarchical organisational structures which work to define students as 'Other'” (p. 5). In my own discipline context, I recognise that, whilst I try to encourage students to research within my teaching, my own role is usually to mark, critique, and feed back on students' research efforts. Thus, I would suspect students in my own department of sport would view the lecturers as the "expert" in teaching, learning and research.

\section{CRITICAL REFLECTIONS ON COLLABORATION IN SOTL PROJECT}

Kreber and Cranton (2000) suggested that scholarship of teaching involves learning through critical reflection based on both research and experience-based knowledge. They proposed a model of the scholarship of teaching which draws from Mezirow's (1991) notion of transformative learning. This model presents three forms of reflection that lead to knowledge development: content reflection, process reflection, and premise reflection. Content reflection takes place at a descriptive level about the problem or issue. Process reflection centres more on questions about how well our efforts in problem solving are working, or the "strategies and procedures of problem solving" (p. 478). Premise reflection is perhaps the most advanced, and relates to more fundamental questions around the worth or merit of the question or issue problem itself; that is, why it was important in the first place.

My critical reflections on my SoTL project began when I sought to make my work public by sending an abstract to the International Scholarship of Teaching and Learning Conference, held in London, in June 2010. While collaboration with students was identified as a key part of this research project methodology, at this time I viewed the collaboration more as a process aspect of the project methodology, leading towards my final "findings," rather than as my central focus or contribution to SoTL. In this abstract, I identified myself and my academic colleague as the authors; however, upon reflection, realized that I had shown a lack of recognition of the students as collaborators. I received notice of acceptance, together with reviewer comments on the abstract, which suggested that the collaborative aspect with students could be potentially inspiring at the conference. The reviewer also queried whether a student would be present at the conference itself.

This insightful feedback led me to undertake deeper, critical content and process re- 
flections about the nature of the project and my own underpinning assumptions about the nature and value of the work - the key element to me being the extent to which I had really achieved the project in "collaboration" with students. I began to reflect further on my project, which had intended to be a SoTL project. Had I been manipulative in order to ensure a good level of data collection? Was my "collaboration" with students merely cursory? Were the interpretations more mine than the students? How did power differentials and my assumptions about students as researchers manifest themselves? How did this affect the potential learning from the project? Why does it matter?

In order to more clearly understand the extent of collaboration I achieved with students, I turned back to the work of Fielding (2001), which examines a project with students as researchers within a secondary school. Within Fielding's (2001) project, four levels of student involvement are identified. These are 1) Students as a data source, 2) students as active responders, 3 ) students as co-researchers, and 4) students as researchers. Fielding recognises that different models and levels of engagement by students and teachers are appropriate at different times and contexts, but suggests it is the level of "student as researchers" that should be strived for, and which reflects transformatory assumptions and values about education and learning. In Fielding's example, it is at this level where students both define the problem and have the power to initiate the investigation and problem solving; whereas, even within students as co-researchers, this is typically tutorled. It is evident that, in moving from Level 1 to Level 4, students become more active in the research and its decision-making.

In the initial focus group interviews and surveys for the SoTL project, I felt students were primarily viewed as "sources of data" — as participants in research, rather than researchers. I suggest that this is not uncommon in much SoTL work. Additionally, students were not explicitly an initial part of the problem formation, as it was I who decided that e-learning was an issue to address. Perhaps had I considered a more enquiry-based approach and encouraged students to engage in a discussion to identify their learning issues and priorities, a different project entirely may have emerged. Hence, as I engaged in process reflection, I reflected that this SoTL project was in danger of reinforcing traditional power boundaries in higher education (Mann, 2001) rather than working in collaboration with students at Level 1 of Fielding's categorisation. In feeding back and asking for student comments on the interpretations of the focus group data and the development of the survey, students did become more "active responders" in the research, as I began to take on board how they perceived the "problem" of e-learning and adapted my survey to more shared goals. Yet, they were still not really equal collaborators, as it was I who developed the questionnaire, rather than putting the full formation of its development in their hands. Sitting down with students to construct the questionnaire together may have been more beneficial in terms of their feeling part of a community of researchers (Brew, 2003). Moreover, did the fact that only three students came forward to help with the subsequent stage perhaps reflect their perception that their work was "done?"

As the project developed, I felt that perhaps the two students who were involved with assisting in gathering the data may have become more "co-researchers," and I turned to these students for more advice, confirmation, and development of ideas. However, it is also notable that these were final year students, and indeed "good" students with whom I already had built a relationship, having taught them the previous year. In addition, I had undertaken the final project write up with my academic collaborator, with verifica- 
tion and agreement, rather than with collaborative input from the remaining students. Perhaps this aspect most clearly reflects the power relations and the assumption that it is the academic who writes up the research for its public dissemination, and the academic who "owns" the work (Mann, 2001).

The greatest extent of collaboration in the research came just prior to and at the conference dissemination event. At that time, one of the students had graduated and was in full time employment - thus a change in status of this student and a change in the lecturer/student power relationship. As a consequence of reflecting on the feedback from our conference abstract (see earlier), and in discussion with my co-presenter, we invited this student who had helped with the project to come with us and present with us at the conference. It was at this time that I became more aware that, rather than the e-learning findings, it was this aspect of exploring how lecturer and students were working together through research to understand how best to develop student learning that was perhaps the crux of our potential contribution to SoTL.

This realisation became clearer through the conference itself, whereby from over a hundred delegates the only student delegate was our newly graduated student. Moreover, when discussing some of the presentations, she turned to me and expressed surprise at the lack of student presence as a conference where "you are all discussing 'us."” This comment, in itself, showed a "them" and "us" divide between students and lecturers, a defining of students as "Other" (Brew, 2006). I reflected on the danger in lecturers distancing themselves from students rather than engaging them in the learning and dissemination process at these events - for surely such conferences are designed to further knowledge about learning, where students are likely to have considerable insight through their experiences. Indeed, the student indicated that if she had known there were conferences where "we" (lecturers) were all discussing how best to help students learn, she would have been much more actively involved in her learning whilst at university. Through this came my understanding that developing students as pedagogic researchers with other students and with lecturers, and truly empowering them in this way, can challenge the traditional authority of knowledge (Bruffee, 1993), and develop a culture where both lecturers and students learn from each other to improve practice and enhance student learning.

The student presented a key part of the conference paper, and received positive feedback from the delegates. It was clear that most questions were directed to the student, and her views were well received. Following the conference, I also received an email from one delegate who asked to cite our work in a piece she was writing in relation to students as researchers. This further reinforced my developing view that this may be the crux of our work in SoTL. A final comment derived from an email from the graduated student following the conference about what she had learned, including that she not only found it "interesting" and "informative" and "thoroughly enjoyed it," but that, having secured employment in a student setting within a different academic institution she had "come away with a few ideas for my own workings with students." This particular relationship, therefore, had certainly impacted and changed the perceptions and engagement of this student. How much more could be achieved by working with students less as sources of data collection, and more through encouraging their involvement as co-researchers or researchers (Fielding, 2001), fully involved in the Scholarship of Teaching and Learning, with associated empowerment and potential for change? 


\section{REFLECTIONS IN CONCLUSION}

This paper is a reflective essay on the notion of "collaboration" in a piece of SOTL practice, which pre-reflexively claimed to be "in collaboration with" students. In such reflection, I suggest that, whilst the project was identified as "collaborative" in nature, student involvement varied from being sources of data to potential co-researchers, but the ideal scenario of student as researcher was not achieved and, I would suggest, rarely is achieved in such projects. Despite a personal constructivist philosophy and desire to work with students to influence change, the nature of higher education institutions is that power relations do exist and are perceived between lecturer and student, with the power and authority resting in the lecturer in obvious, subtle and also taken for granted ways (Mann, 2001). Such relations are played out and often reinforced in our everyday relations with students. Unless we critically reflect on these power relations in our actions and consciously empower students, the greatest potential in collaborative learning through SoTL may be lost. Yet, it is also important for lecturers to engage in premise reflection to consider why the goal of working collaboratively and developing students as researchers within SoTL “matters" (Kreber, 2007). It matters because of the potential impact on student engagement and learning, and the way it can potentially challenge both the traditional power balance and the nature of higher education itself.

Linda Allin is a University Teaching Fellow and principal lecturer in the Department of Sport, Exercise and Rehabilitation, at the University of Northumbria (UK).

\section{REFERENCES}

Allin, L., Turnock, C., \&Thomspon, J. (2011). Enhancing teaching and learning with technology through collaborative research with students. In J. Fanghanel, D. Bernstein, M. Huber, D. Berthiaume, D. Warren, T. Roxa., \& N.R. Colet (Eds.) Disciplines, pedagogies and cultures for SoTL, The London Scholarship of Teaching and Learning 8th International Conference Proceedings, 13-14 May 2010 (pp.9-16). University of West London.

Boyer, E.L. (1990). Scholarship reconsidered: priorities of the professoriate. Princeton, NJ: The Carnegie Foundation.

Brew, A. (2003). Teaching and research: New relationships and their implications for inquirybased teaching and learning in higher education. Higher Education Research and Development, 22(1), 3-18.

Brew, A. (2006). Research and teaching: Beyond the divide. London: Palgrave.

Bruffee, K. A. (1993). Collaborative learning; Higher education, interdependence, and the authority of knowledge. London: The Johns Hopkins University Press.

Dillenbourg P. (1999). What do you mean by collaborative learning? In P. Dillenbourg (Ed.) Collaborative-learning: Cognitive and computational approaches (pp.1-19). Oxford: Elsevier.

Felton, P. (2013). Principles of good practice in SoTL. Teaching and Learning Inquiry, 1(1), $121-125$.

Fielding, M. (2001). Students as radical agents of change, Journal of Educational Change. 2(2), 123-121. 
Healey, M. (2005). Linking research and teaching to benefit student learning, Journal of Geography in Higher Education. 29(2), 183-201.

Kreber, C. (2007). What's it really all about? The Scholarship of Teaching and Learning as an authentic practice. International Journal for the Scholarship of Teaching and Learning, 1(1), 1-4 Retrieved from: http://academics.georgiasouthern.edu/ijsotl/v1n1/essays/kreber /IJ_Kreber.pdf (Accessed 16 May, 2013).

Kreber, C., \& Cranton, P.A. (2000); Exploring the scholarship of teaching. Journal of Higher Education, 71(4), 476-496.

Mann, S. J. (2001). Alternative perspectives on the student experience: Alienation and engagement. Studies in Higher Education, 26(1), 7-19.

Mezirow, J. (1991). Transformative dimensions of adult learning. San Francisco: Jossey-Bass.

Norton, L. S. (2009). Action research in teaching and learning. London: Routledge.

Palincsar, A. S. (1998). Social constructivist perspectives on teaching and learning. Annual Review of Psychology, 49, 345-75.

Robertson, J., \& Blackler, G. (2006) Students' experiences of learning in a research environment. Higher Education Research and Development 25(3), 215-229

Salmon (2007). E-activities: The key to active on-line learning. London: Routledge.

Sharpe, R., and Benfield, G. (2005) The student experience of e-learning in higher education: A review of the literature. Brookes eJournal of Learning and Teaching, 1(3), 1- 7.

Solomon, N., Boud, D., Leontios, M., \& Staron, M. (2001). Tale of two institutions: Exploring collaboration in research partnerships, Studies in the Education of Adults, 33(2), 135-142.

Werder, C., \& Otis, M. (2009). Engaging student voices in the study of teaching and learning. Sterling VA: Stylus.

Willison, J., \& O'Regan, K (2007). Commonly known, commonly not known, totally not known: A framework for students becoming researchers. Higher Education Research and Development, 26(4), 393-409. 